\title{
Az ESC/EAS 2019. évi lipidajánlása, az LDL-koleszterin-célérték elérésének lehetőségei szívinfarktuson átesett, igen nagy kockázatú betegekben
}

\author{
Márk László', Reiber István², Bajnok László3
}

\author{
1'Békés Megyei Központi Kórház, Pándy Kálmán Tagkórház, Kardiológia Osztály, Gyula \\ ${ }^{2}$ Fejér Megyei Szent György Egyetemi Oktató Kórház, Székesfehérvár \\ ${ }^{3}$ Pécsi Tudományegyetem, Klinikai Központ, I. sz. Belgyógyászati Klinika, Endokrinológiai és \\ Anyagcsere Tanszék, Pécs \\ Levelezési cím: \\ Dr. Márk László, Békés Megyei Központi Kórház, Pándy Kálmán Tagkórház, Kardiológia Osztály \\ 5700 Gyula, Semmelweis u. 1. E-mail: dr.mark.laszlo@gmail.com
}

2019 őszén jelent meg az Európai Kardiológusok Társasága és az Európai Atherosclerosis Társaság (ESC/EAS) közös dyslipidaemiaajánlása. Ennek egyik legnagyobb újdonsága, hogy az utóbbi 3 évben közölt nagy klinikai vizsgálatok eredményei alapján alacsonyabb LDL-koleszterin-célértékeket irányoz elő. Ezek elérése, ismerve a jelenlegi napi gyakorlatot, még nagyobb odafigyelést igényelne az orvosok, és még jobb adherenciát a betegek részéről. Ugyanakkor hangsúlyozandó, hogy az igen nagy kockázat 1,4 mmol/l célértéke, vagy 2 éven belül ismétlődő éresemény esetén az $1,0 \mathrm{mmol} / \mathrm{l}$ elérése nagy kihívás a statin- és a statin+ezetimib kombinációs terápiának is. Az ezetimib nagyobb arányú alkalmazása mellett gyakran jönne szóba PCSK9-gátló adása. Ezen megállapítások fokozottan érvényesek a szívinfarktusok vagy koronáriaintervención átesett betegekre, ők nyernék a legtöbbet az előírások szerint végzett lipidcsökkentéssel.

Kullcsszavak: irányelvek, lipidológia, koleszterin, statin, ezetimib, PSCK9-gátlók

The 2019 dyslipidaemia guideline of the ESC/EAS and the availability of the LDL-cholesterol goal attainment in very high risk patients after myocardial infarction

The new dyslipidaemia guideline of the European Society of Cardiology and European Atherosclerosis Society was published on autumn of 2019. Its novelty was that based on the studies of the latest 3 years the LDL-cholesterol target level had been decreased. Being aware of the present daily practice for the attainment of the new goals more attention has to be paid by the doctors and would require a better adherence from patients. It has to be underlined that the achievement of $1.4 \mathrm{mmol} / \mathrm{L}$ LDL-cholesterol level or that of $1.0 \mathrm{mmol} / \mathrm{l}$ in the case of recurrent cardiovascular event within 2 years is a great challenge for the statin and combined statin+ezetimibe therapy as well. Beside the more frequent administration of the ezetimibe the use of PCSK9-inhibitors would be needed. These statements are highly valid for the patients after myocardial infarction and percutaneous intervention since they would expect most benefit from an adequate lipid lowering therapy.

Keywords: guidelines, lipidology, cholesterol, statins, ezetimibe, PCSK9-inhibitors

A kezelési irányelvek összefoglalják azokat a bizonyítékokat, amelyek alapján az útmutatót kiadó testület a legjobb tudása szerint az egyes betegek kezelését a kezelőorvosok felé ajánlja. A 2016-ban megjelent Eu- rópai Kardiológiai Társaság és Európai Atherosclerosis Társaság (ESC/EAS) közös dyslipidaemiaajánlása után a korábbi 5 helyett csak 3 évet váratott magára az új bejelentés a párizsi európai kardiológuskongresszuson. 
Az ajánlás írói neves európai szakértők (1).

Minden irányelv annyit ér, amennyi megvalósul belőle. Ismerve a lipidcsökkentés elveinek érvényesülését, azt, hogy az ajánlott célértékek elérése milyen messze van a kívánatostól, felmerülhet bennünk a kérdés, hogy szükség van-e újabb, az eddiginél szigorúbb célértékeket előíró ajánlásokra akkor, ha a régieket sem tartjuk be. Egyértelműen igen! Az irányelvek íróinak az a feladatuk, hogy az új vizsgálati eredmények alapján összefoglalják, hogy milyen kezeléssel járnának legjobban a betegek, hogyan lehetne a legjobban lecsökkenteni a kardiovaszkuláris események számát. $A z$, hogy a korábbi elvek megvalósulása is messze van az elfogadhatótól, nem elég ahhoz, hogy a legújabb klinikai vizsgálatok alapján bizonyított előnyökről lemondjunk. Ráadásul egy új összefoglaló mindig reményt ad arra is, hogy a kollégák jobban megismerik és elfogadják az újabb eredményeket. Reméljük, hogy a hazai ismertetések $(2,3,4)$ egy lökést adnak a magyar prevenciós törekvéseknek is.

\section{A kardiovaszkuláris kockázat élethosszi megközelítése (lifetime approach to risk)}

Az új ajánlás hangsúlyozza, hogy az ateroszklerotikus kardiovaszkuláris betegség (ASCVD) elleni harcnak nem a betegség felismerésekor, nem is az ahhoz vezető, nagy kockázati tényezőknek a megjelenésekor kell kezdődnie, hanem stratégiával kell rendelkeznünk minden életkorban, többek között arra kell biztatni mindenkit, hogy egészséges életvitelt folytasson (5). Az egyetemes kardiológia nagy ikonja, Eugen Braunwald, aki 2019-ben töltötte be 90 . életévét, párizsi európai kardiológuskongresszuson tartott előadásában ismételten hangsúlyozta a lipidcsökkentés vitathatatlan szerepét az ateroszklerózis megelőzésében és kezelésében, és annak hosszú távú folytatásának jelentőségét (6).

Arra, hogy a rizikófaktorok kezelését, vagy akár a kialakulásuk megelőzését (primordiális prevenció) korán kell elkezdeni, az ajánlások és maga Braunwald is régóta figyelmeztetnek (7). A világ 52 országában végzett INTERHEART-vizsgálat azt igazolta, hogy 9, viszonylag jól befolyásolható nagy rizikófaktor (dohányzás, ApoB/ ApoA1 arány, diabétesz, hipertónia, abdominalis obesitas, pszichoszociális faktorok, mozgásszegény életmód, kevés zöldség és gyümölcs fogyasztása és túlzott alkoholfogyasztás) a felelős a kockázat több mint 90\%-áért (8).

A hosszú távú kockázatcsökkentés hasznára a legjobb példát a mendeli randomizációs vizsgálatok adják, amelyekben a randomizálást lényegében a természet maga végzi: valamilyen genetikai eltéréssel rendelkező és nem rendelkező betegek adatait hasonlítják öszsze. A módszer hátránya, hogy nagy betegszámon kell genetikai vizsgálatokat végezni a kívánt genetikai abnormitások elegendő számú megtalálásához, egye- di óriási előnye viszont a hosszú követési idő. Ference és munkatársai 438 ezer, az Egyesült Királyságban genetikai vizsgálaton (UK Biobank) átesett egyed közel 25 ezer koronáriaeseményének és 100 genetikailag $15,1 \mathrm{mg} / \mathrm{dl}=0,39 \mathrm{mmol} / \mathrm{l}-\mathrm{rel}$ alacsonyabb LDL-C, és 61, a szisztolés vérnyomás 2,9-3 Hgmm-rel alacsonyabb értékével járó polimorfizmusainak kapcsolatát elemezték. Azt állapították meg, hogy azokban, akikben a két kedvező genetikai eltérés egyszerre fordult elő, az alacsonyabb LDL-C-t $1 \mathrm{mmol} / \mathrm{l}-\mathrm{re}$, és a szisztolés vérnyomást 10 Hgmm-re extrapolálva 78\%-kal alacsonyabb a kardiovaszkuláris kockázat (9). Ez azt igazolja, hogy a hosszú ideig fennálló, akár kismértékűnek is tűnő vérnyomás vagy LDL-C-javításnak is jelentős hosszú távú kockázatcsökkentő hatása van.

Ha későbbi életkorban kezdjük el a kezelést, az elérhető haszon kisebb. Minél veszélyeztetettebb a beteg, annál nagyobb a kezeléstől várható nyereség. A Cholesterol Treatment Trialists' Collaboration 170 ezer, statint szedő betegének adatai alapján kalkulálva, ha 2,5 mmol/l-ről csökkentjük 1,8-re az LDL-koleszterint, 100 beteg kezelésével 10 év alatt három szívinfarktus, stroke vagy kardiovaszkuláris haláleset lenne elkerülhető (10).

\section{Az ajánlás néhány kiemelendő eleme}

A lipidcsökkentés folyamata továbbra is a kockázatbecsléssel, a kockázati kategóriába sorolással kezdődik, amelynek alapja a meglévő betegségek és/vagy a SCORE-táblázatok figyelembe vétele. Ez utóbbinak egy problémája, hogy fiatalokon (40 év alatt) lényeges, nagy rizikófaktorok jelenlétében is az abszolút kardiovaszkuláris kockázat kicsinek számíthat, holott az előzőleg tárgyalt élethosszi kockázat igen nagy. A VII. Magyar Kardiovaszkuláris konszenzuskonferencia táblái között is szerepel az ilyenkor alkalmazandó relatív kockázatbecslés lehetősége (11).

A carotis vagy femoralis plakk kimutatása és a koronária calcium score Ila osztályú, B-szintű ajánlás. A plakkok noninvazív vizsgálata tünetmentes, kis vagy közepes kockázatú és statinterápiára jelölt betegeken jöhet szóba. A nem szignifikáns plakk jelenléte is gondozást és szigorú kezelést igényel.

A familiáris hypercholesterinaemia $(\mathrm{FH})$ egy további rizikófaktor jelenléte esetén igen nagy, anélkül nagy kockázatba történő besorolást jelent.

Természetesen a 2019-es ESC/EAS-ajánlás is hangsúlyozza a lipidcsökkentő gyógyszeres kezelés előtti és melletti egészséges életmód következetes tartását, amely magába foglalja az energiatudatos, állati zsírokban és egyszerủ szénhidrátokban szegényebb, növényi és halolajban gazdag, rostdús, változatos táplálkozást, a rendszeres testmozgást, az aktív és passzív dohányzásmentességet és a lehetőség szerinti stresszoldó magatartást.

Az új ajánlásban külön fejezetben foglakozik az $\mathrm{FH}$, a 
nők, idősebb betegek, diabéteszesek és metabolikus szindrómások, perifériás érbetegek, krónikus vesebetegek, valamint akut koronáriaszindrómán és stroke-on átesett betegek kezelésével. A cukorbetegségről szóló rész hivatkozik magyar szerzők diabéteszes betegek lipideredményeinek elemzésével született közlésére, amely szerint diabéteszben fokozott jelentősége lenne a non-HDL-C használatának (12).

\section{A kockázat lipidmarkerei}

Az új ajánlás egyértelműen megfogalmazza, hogy az emelkedett LDL-C és ezenkívül minden apolipoprotein-B-t tartalmazó lipidrészecskében lévő koleszterin együttesen az ateroszklerózis talaján kialakuló vaszkuláris érelváltozások, betegségek és halálozás rizikótényezője. Bizonyítékul szolgál epidemiológiai, genetikai és lipidcsökkentő gyógyszerekkel folytatott klinikai eseményeket követő vizsgálatok nagy száma.

A 2019-es európai útmutató véleménye szerint a kardiovaszkuláris rizikóállapot megállapításához és a lipidcsökkentő kezelés hatásosságának a követéséhez a vérzsírparaméterek meghatározását nem kell éhgyomri vérmintából végezni. A szükséges alapmeghatározások az összkoleszterin- (TC), a HDL-C-, az LDL-C- és a TG-értékek (I/C). A direkt LDL-C mérésének hiányában (ezt nálunk nagyon kevés helyen végzik) az LDL-C számításához (TC, HDL, TG ismeretében) a jelen ajánlás is a pontosabb értéket adó Martin/Hopkins-féle meghatározást javasolja az eddig használatos, nálunk eddig egyeduralkodó Friedewald-féle kalkuláció helyett (13). Magasabb TG (>2,3 mmol/l) esetén hasznos további információkat adhat a vaszkuláris rizikóállapotról a nonHDL-C meghatározása (TC - HDL-C) (I/C), különösen diabetes mellitusban, obesitasban, illetve metabolikus szindrómában. LDL-C vagy non-HDL-C helyett I/C erősségủ az előbb felsorolt állapotokban az apolipoprotein-B közvetlen meghatározása, de ez sajnos hazánkban még a lipidológiai és kardiológiai központokban sem mindenhol adott. Ugyanígy problémát jelent a lipoprotein(a) (Lp[a]) meghatároztatása is Magyarországon, pedig az ajánlás szerint mindenkinek legalább egyszer életében mérni kellene az Lp(a)-szintjét (Ila/C), amely genetikailag meghatározott, magas értéke a kockázatot módosíthatja. A nagyon magas szint (430 mmol/l felett) a beteg az élethosszig tartó kockázat nagysága miatt úgy kezelendő, mint egy heterozigóta FH (1. táblázat).

\section{A célértékek módosítása}

Az igazi, bombasztikus változást a 2019-es európai ajánlásban az LDL-C terápiás célértékeinek másfél évtized után történő módosítása jelenti. Az igen nagy kockázatú kategória és a hozzátartozó 1,8 mmol/l LDLC-cél 2004-ben jelent meg, opcionálisan, amikor az
1. TÁBLÁZAT. Ajánlott lipidvizsgálatok

Ajánlások

TC-meghatározás a teljes kardiovaszkuláris rizikó megállapításához (SCORE)

HDL-C-meghatározás rizikófinomításhoz (SCORE)

LDL-C-meghatározás az ajánlott elsődleges lipidvizsgálat-szűréshez, -diagnózishoz, -terápiához

TG-mérés a rutin lipidvizsgálat ajánlott része kell legyen

Non-HDL-C-meghatározás javasolt magasabb TG, DM, obesitas vagy nagyon alacsony LDL-C esetén

ApoB-mérés javasolt magasabb TG, DM, obesitas, MetSy vagy nagyon alacsony LDL-C esetén. (LDL-C vagy non-HDL-C helyett)

Lp(a) mérése megfontolandó legalább egyszer az élet folyamán az igen magas szint (>180 mg/dl) tisztázásához ( $\mathrm{FH}$ equivalens rizikó)

Lp(a) mérése megfontolandó családi kardiovaszkuláris rizikónál, rizikóreklasszifikációnál (mérsékelt-nagy kardiovaszkuláris kockázat)

\begin{tabular}{|c|c|}
\hline Osztály & Szint \\
\hline I & C \\
\hline I & C \\
\hline I & C \\
\hline I & C \\
\hline I & C \\
\hline I & C \\
\hline Ila & C \\
\hline Ila & C \\
\hline
\end{tabular}

USA-ban a National Cholesterol Education Program Adult Treatment Panel III (ATP-III) 2001. évi bevezetése (14) után közölt tanulmányok eredményei alapján az amerikai társaságok kidolgozták és közreadták a korábbi ajánlásaik új változatát (15).

Az új európai ajánlás szerint szekunder prevencióban és az egyéb igen nagy kardiovaszkuláris rizikóval terhelt betegeknél az elérendő LDL-C-célérték 1,4 mmol// alatt kell hogy legyen (a korábbi 1,8 alatti cél helyett) és legalább $50 \%$-os csökkentés szükséges a kiindulási LDL-C-szinthez képest (I/A). Primer prevencióban igen nagy kockázat esetén ugyanezen szigorú célok érendők el, $\mathrm{FH}$ nélkül I/C, $\mathrm{FH}$ esetén Ila/C erősséggel. Olyan érbetegnél, akinél a tolerálható maximális dózisú, statinalapú terápia mellett 2 éven belül újabb éresemény jelentkezik (nem kell, hogy azonos érszakaszon legyen), megfontolható az 1,0 mmol/l alatti LDLC-érték elérendő célként (IIb/B). Nagy kardiovaszkuláris rizikójú betegnél az ajánlott LDL-C-célérték kisebb mint 1,8 mmol/l (a korábbi 2,6 mmol/l alatti helyett), és legalább 50\%-os szintcsökkentés szükséges a kiindulási LDL-C-hez képest (I/A). Mérsékelt kockázat mellett megfontolandó a 2,6 mmol/l alatti (Ila/A), alacsony kockázat esetén pedig megfontolható a 3,0 mmol/l alatti (Ilb/A) LDL-C-szintek biztosítása (2. táblázat).

Ezek alapján került összeállításra egy táblázat, amelyben a kezeletlen LDL-C-szintek és a kardiovaszkuláris rizikóállapot (primer és szekunder prevencióban) függvényében látható, hogy milyen kezelési stratégiával mekkora LDL-C-csökkenés érhető el (3. táblázat). 
2. TÁBLÁZAT. Az ESC/EAS 2019. évi lipidirányelveinek célértékei a különböző kockázati kategóriákban

\begin{tabular}{|c|c|c|c|}
\hline Kockázat & LDL-C-cél & Osztály & Szint \\
\hline $\begin{array}{l}\text { Igen nagy + re- } \\
\text { cidív esemény }\end{array}$ & $<1,0 \mathrm{mmol} / \mathrm{l}$ & Illb & B \\
\hline Igen nagy & $\begin{array}{l}<1,4 \mathrm{mmol} / \mathrm{l}+\text { legalább } \\
50 \% \text {-os csökkentés }\end{array}$ & I & $A-C$ \\
\hline Nagy & $\begin{array}{l}<1,8 \mathrm{mmol} / \mathrm{l}+\text { legalább } \\
50 \% \text {-os csökkentés }\end{array}$ & I & A \\
\hline Közepes & $<2,6 \mathrm{mmol} / \mathrm{l}$ & Ila & $\mathbf{A}$ \\
\hline Alacsony & $<3,0 \mathrm{mmol} / \mathrm{l}$ & Illb & A \\
\hline
\end{tabular}

\section{Az LDL-C gyógyszeres kezelése}

Az LDL-C-csökkentés gyógyszeres kezelésében változatlanul a hatásos dózisú, rendszeres statinterápiát kell alapul venni. Az új útmutatóban továbbra is I/A erősségű ajánlásként szerepel, hogy nagy intenzitású statin (20-40 mg rosuvastatin vagy 40-80 mg atorvastatin) adása kívánatos a rizikóstátusznak megfelelő LDL-C-célértékek eléréséhez (4. táblázat). A nagy intenzitású statinokkal bár a betegek többségénél elérhető a kívánatos 50\%-os csökkenés, de az új, szigorúnak tűnő 1,4 mmol// alatti LDL-C-célérték biztosítását csak kb. 50\%-ban teszi lehetővé. Amennyiben a maximálisan tolerálható statin adásával a szükséges LDL-C-cél nem elérhető, akkor a következő lépés a statin és ezetimib kombinációs terápia kell hogy legyen (I/B). A nagy intenzitású statin és az ezetimib együttes adásával a kiindulási LDL-C-szint $65-70 \%-k a l$ is csökkenthető. Szekunder prevencióban igen nagy kockázatú betegnél, ha a következetesen alkalmazott maximálisan tolerálható statin és ezetimib adásával sem sikerül elérni a kívánatos LDL-C-célértéket, akkor PCSK9-gátló terápiával való kiegészítés javasolt (I/A) (4. táblázat). Ez utóbbi sajnos hazánkban pillanatnyilag nem támogatott lehetőség, csak súlyosan progrediáló érbetegség esetén egyéni elbírálás alapján tudjuk a megfelelő keze- lést biztosítani betegeinknek. További hazai probléma az ezetimib felírhatóságának a szakorvosi javaslathoz kötöttsége és a kizárólagosan érkatasztrófa utáni állapotban adhatósága, holott ezetimib nélkül a célértékek elérése sokszor nem lehetséges.

\section{Tanulságok a szívinfarktuson vagy perkután intervención átesett betegek lipidcsőkkentő kezelésével kapcsolatban}

Az igen nagy kockázatú kategórián belül a szívinfarktuson (AMI) és/vagy perkután koronáriaintervención ( $\mathrm{PCl}$ ) átesett betegek azok, akik számára a legfontosabb az előírás szerinti lipidcsökentés, ők nyerhetnek a legtöbbet a célértékek elérésével. A korábbi 1,8 mmol// LDL-C-szint elérése sem valósult meg elégséges szinten (10), az 1,4, illetve az 1,0 mmol// még nagyobb kihívást, még nagyobb odafigyelést igényelne az orvosok részéről.

Ha a tolerált legnagyobb statinadaggal nem érjük el az $1,4 \mathrm{mmol} / \mathrm{l}$ LDL-C-célértékeket, akkor ezetimib adása is szükséges. Jó, hogy ezen betegek esetében a magyar szabályozás sem szab gátat az ezetimib felírásának (bár az eü. pont azon korlátja, hogy előzetesen 3 hónapos statinadás szükséges, nem észszerű korábbi statinterápia mellett kialakult AMI vagy statinintolerancia esetén). Cannon és munkatársai amerikai gyógyszerpiaci adatbázison alapuló, 2017-es közlése szerint az 1,8 mmol/l LDL-C-célérték elérésének esélye maximális intenzitású atorvastatin mellett $69 \%$, ezetimib hozzáadásával $86 \%$ (16). Mindez akkor valósulna meg, ha az orvosok az irányelveknek megfelelően írnák elő a kezeléseket, és a betegek ideálisan működnének ebben együtt. Természetesen az 1,4 mmol/l elérése még nehezebb. A Cannon-elemzés továbbgondolása és azon hazai gyakorlat alapján, hogy az intenzív statinkezelés általában szubmaximális adagokkal történik, az 5. táblázat azt mutatja meg, hogy milyen az egyes veszélyeztetettségi kategóriákban a célértékek elérésének valószínűsége

\section{TÁBLÁZAT. Elérhető LDL-C-szintek a különböző lipidcsökkentő terápiákkal (mmol/l)}

\begin{tabular}{|c|c|c|c|c|c|}
\hline \multirow{2}{*}{$\begin{array}{l}\text { Kiindulási } \\
\text { LDL-C mmol// }\end{array}$} & \multicolumn{2}{|c|}{ Mérsékelt intenzitású statin } & \multicolumn{2}{|c|}{ Nagy intenzitású statin } & \multirow{2}{*}{$\begin{array}{c}\text { PCSK9-gátló + } \\
\text { nagy intenzitású } \\
\text { statin }\end{array}$} \\
\hline & Monoterápia & + Ezetimib & Monoterápia & +Ezetimib & \\
\hline 4,5 & 3,2 & 2,5 & 2,3 & 1,6 & 0,9 \\
\hline 4,3 & 3,0 & 2,4 & 2,2 & 1,5 & 0,9 \\
\hline 4,0 & 2,8 & 2,2 & 2,0 & 1,4 & 0,8 \\
\hline 3,7 & 2,6 & 2,0 & 1,9 & 1,3 & 0,7 \\
\hline 3,5 & 2,5 & 1,9 & 1,8 & 1,2 & 0,7 \\
\hline 3,2 & 2,2 & 1,8 & 1,6 & 1,1 & 0,6 \\
\hline 3,0 & 2,1 & 1,7 & 1,5 & 1,1 & 0,6 \\
\hline 2,7 & 1,9 & 1,5 & 1,4 & 0,9 & 0,5 \\
\hline 2,5 & 1,8 & 1,4 & 1,3 & 0,9 & 0,5 \\
\hline 2,2 & 1,5 & 1,2 & 1,1 & 0,8 & 0,4 \\
\hline 1,9 & 1,3 & 1,0 & 1,0 & 0,7 & 0,4 \\
\hline
\end{tabular}


4. TÁBLÁZAT. Az LDL-C-csökkentés ajánlott gyógyszeres kezelése

Ajánlások

Nagy intenzitású statin adása ajánlott a rizikóstátusznak megfelelő célérték eléréséhez (maximálisan tolerálható dózistól felfelé)

Ha a maximálisan tolerálható statinnal a cél nem elérhetö, ezetimibbel kell kombinálni a statint

Primer prevencióban igen nagy kockázat esetén ( $\mathrm{FH}$ nélkül), ha a cél nem elérhető max. tolerálható statin + ezetimib adásával - PCSK9i-kiegészítés megfontolható

Szekunder prevencióban igen nagy kockázat esetén, ha a cél nem elérhető max. tolerálható statin + ezetimib adásával - PCSK9i-kiegészítés javasolt

Igen nagy kockázat + FH esetén, ha a cél nem elérhető max. tolerálható statin + ezetimib adásával - PCSK9i-kiegészítés megfontolandó

Ha a statin nem tolerált semmilyen dózisban, típusban - ezetimib adása megfontolandó

Ha a statin nem tolerált semmilyen dózisban, típusban - ezetimib + PCSK9i együttes adása megfontolható

Ha a cél nem elérhető, statin + epesavkötő kombináció megfontolható

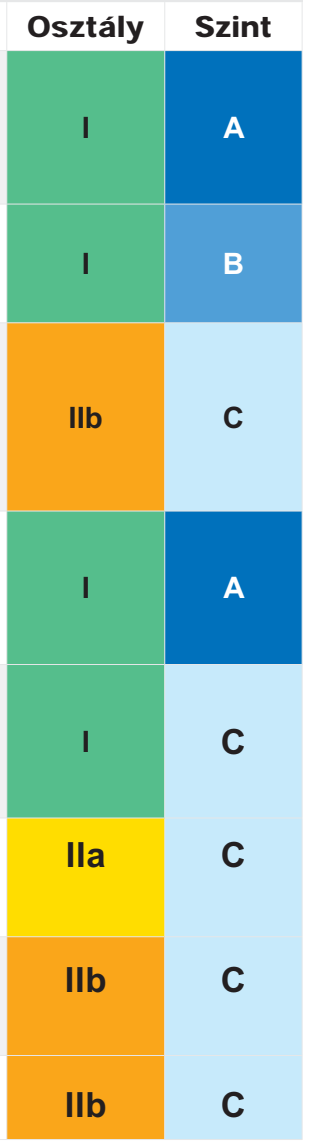

a különböző tablettás koleszterincsökkentési lehetőségekkel $(2,16)$. Az 1,4 mmol/l elérésének esélye nagy intenzitású statinokkal is csak $50 \%$, ami ezetimibbel kombinálva 66\%-ra emelhető, a fennmaradó 34\%-ban a PCSK9-gátlók adása jönne szóba (2). Ezek az arányok lényegesen rosszabbak, ha $1,0 \mathrm{mmol} / \mathrm{l}$ elérése lenne szükséges.

A számadatok azt sugallják, hogy $A M I$ vagy $P C l$ utáni betegekben a jobb célérték elérési arány érdekében az ezetimib adása az esetek felében elengedhetetlen és egyúttal a PCSK9-gátlók gyakoribb alkalmazásának szükségességét vetítik előre.

5. TÁBLÁZAT. Az LDL-C-célértékek elérésének valószínűsége a különböző tablettás koleszterincsökkentési stratégiákkal

\begin{tabular}{|c|c|c|c|c|}
\hline \multirow{2}{*}{ Kockázat } & \multirow{2}{*}{$\begin{array}{l}\text { LDL-C } \\
\text { cél } \\
\text { (mmol/l) }\end{array}$} & \multicolumn{2}{|c|}{$\begin{array}{c}\text { Statin } \\
\text { monoterápia }\end{array}$} & \multirow{2}{*}{$\begin{array}{l}\text { Intenzív } \\
\text { statin + } \\
\text { ezetimib }\end{array}$} \\
\hline & & $\begin{array}{l}\text { Mérsé- } \\
\text { kelt }\end{array}$ & $\begin{array}{l}\text { Inten- } \\
\text { zív }\end{array}$ & \\
\hline $\begin{array}{l}\text { Igen nagy + re- } \\
\text { cidív esemény }\end{array}$ & $<1,0$ & $10 \%$ & $14 \%$ & $16 \%$ \\
\hline Igen nagy & $<1,4$ & $25 \%$ & $50 \%$ & $66 \%$ \\
\hline Nagy & $<1,8$ & $50 \%$ & $66 \%$ & $75 \%$ \\
\hline Mérsékelt & $<2,6$ & $66 \%$ & $75 \%$ & $99 \%$ \\
\hline
\end{tabular}

\section{Nyilatkozat}

A szerzők kijelentik, hogy a közlemény megírásával kapcsolatban nem áll fenn velük szemben pénzügyi vagy egyéb lényeges összeütközés, összeférhetetlenségi ok, amely befolyásolhatja a közleményben bemutatott eredményeket, az abból levont következtetéseket vagy azok értelmezését.

Irodalom

1. Mach F, Baigent C, Catapano AL, et al; ESC Scientific Document Group. 2019 ESC/EAS Guidelines for the management of dyslipidaemias: lipid modification to reduce cardiovascular risk. Eur Heart J 2020;41:111-188. doi: 10.1093/eurheartj/ehz455.

2. Bajnok L. Az Európai Ateroszklerózis Társaság (EAS) és az Európai Kardiológiai Társaság (ESC) dyslipidaemia ajánlása. Fókuszban az igen nagy kockázatúak. Metabolizmus 2019; 17: 262-265.

3. Barna I. Kisebb célértékek a lipidcsökkentő terápiában. Háziorvos Továbbképző Szemle 2019; 24: 658-660.

4. Bajnok L. A dyslipidaemia és kezelése - az újabb irányelvek tükrében. Kardio-vaszkuláris Iránytű 2019; 1(3): 21-28.

5. Berry JD, Dyer A, Cai X, et al. Lifetime risks of cardiovascular disease. N Engl J Med 2012; 366: 321-329. doi: 10.1056/NEJMoa1012848. 6. Braunwald $\mathrm{E}$. What is the right age to start lipid-lowering therapy? Professor Braunwald's perspective on lipid lowering. European Society of Cardiology Congress 2019; Paris, France; Presented September, 2019. 7. Braunwald $E$. The rise of cardiovascular medicine. Eur Heart $J$ 2012; 33: 838-846. doi: 10.1093/eurheartj/ehr452.

8. Yusuf S, Hawken S, Ounpuu S, Dans T, et al. Effect of potentially modifiable risk factors associated with myocardial infarction in 52 countries (the INTERHEART study): case-control study. Lancet 2004; 364: 937-952. doi: 10.1016/S0140-6736(04)17018-9

9. Ference $B A, B$ hatt $D L$, Catapano $A L$, et al. Association of genetic variants related to combined exposure to lower Low-Density Lipoproteins and lower systolic blood pressure with lifetime risk of cardiovascular disease. J AMA. 2019; 322: 1381-1391. doi: 10.1001/jama.2019.14120. 10. Márk L. Hány cardiovascularis eseményt előzhetünk meg a prevenciós elvek szerint vezetett lipidcsökkentő kezeléssel? LAM 2019; 29: 289-294. doi: https://doi.org/10.33616/lam.29.029

11. A VII. Magyar Kardiovaszkuláris Konszenzus Konferencia ajánlásai. Metabolizmus 2018; 16: 1-66.

12. Márk L, Vallejo-Vaz AJ, Reiber I, Paragh Gy, et al. Non-HDL cholesterol goal attainment and its relationship with triglyceride concentrations among diabetic subjects with cardiovascular disease: a nationwide survey of 2,674 individuals in Hungary. Atherosclerosis 2015; 241: 62-68. doi: 10.1016/j.atherosclerosis.2015.04.810.

13. Reiber I, Márk L, Paragh Gy. Akkor most LDL-koleszterin vagy non-HDL-koleszterin? Metabolizmus 2018; 16: 259-264.

14. Expert Panel on Detection, Evaluation, and Treatment of High Blood Cholesterol in Adults. Executive Summary of the Third Report of the National Cholesterol Education Program (NCEP) Expert Panel on Detection, Evaluation, and Treatment of High Blood Cholesterol in Adults (Adult Treatment Panel III). JAMA 2001; 285: 2486 2497. doi 10.1001/jama.285.19.2486

15. Grundy SM, Cleeman JI, Merz CNB, et al. Implications of recent clinical trials for the National Cholesterol Education program Adult Treatment Panel III guidelines. Circulation 2004; 110: 227-239. doi: 10.1161/01.CIR.0000133317.49796.0E

16. Cannon CP, Khan I, Klimchak A, et al. Simulation of lipid-lowering therapy intensification in a population with atherosclerotic cardiovascular disease. JAMA Cardiol 2017; 2: 959-966. doi: 10.1001/ jamacardio.2017.2289. 